\title{
Development of an Enzyme Immunoassay for Poliovirus Antigens
}

\author{
Newton Hashimoto, Fabrício José Benati, Flávio Lauretti, Rosa Elisa Carvalho Linhares \\ and Carlos Mitihiko Nozawa* \\ Departamento de Microbiologia; CCB; Universidade Estadual de Londrina; C. P. 6001; 86051-970; Londrina - PR \\ - Brasil
}

\begin{abstract}
An indirect solid-phase enzyme immunoassay (EIA) was developed for the detection of poliovirus antigen. Virus antigen was obtained in $\mathrm{LLC}-\mathrm{MK}_{2}$ cell cultures and used to prepare antibodies in rabbit and guinea pig. Antibodies were evaluated by double immunodiffusion and neutralization test. Optimal concentrations of guinea pig and rabbit immunoglobulins were determined by checkerboard titration. Microtitre plates were coated with $15.0 \mu \mathrm{g} / \mathrm{ml} \mathrm{guinea}$ pig anti-polio immunoglobulin and rabbit anti-polio immunoglobulin at the concentration of $7.94 \mu \mathrm{g} / \mathrm{ml}$ was used as detecting antibody. The standard curve with eight different antigen concentrations in eight replicates resulted in a coefficient of variation $(\mathrm{CV})$ between $2.1 \%$ to $7.8 \%$. The dose-response relationship was determined by simple linear regression with a coefficient of correlation $\left(R^{2}\right)$ equal to $96.4 \%$. The assay detected a minimum of $2.3 \mu \mathrm{g} / \mathrm{ml}$ poliovirus antigen.
\end{abstract}

Key words: Enzyme immunoassay, Poliovirus antigen

\section{INTRODUCTION}

The approaches for laboratory diagnosis of virus infection have been the isolation of the agent and/or detection of viral antigen, viral genome and serology (Lennette, 1995; Engleberg, 1999). The best methods should fulfill the five main prerequisites: speed, simplicity, sensitivity, specificity and low cost. Tests for viral antigen, which provide a diagnosis from a single specimen, are rather important for many purposes. Solidphase enzyme immunoassay (EIA) is one of the methods of choice. Poliovirus, a member of the family Picornaviridae, genus Enterovirus, was responsible for the legacy of paralysis and deformity, since the fifties. The virus still poses a threat as the cause of poliomyelitis mainly in some underdeveloped countries (Pallansch and Roos,
2001). The identification of poliovirus relies mainly on the serum neutralization test (Nt) (Payment et al., 1982; Wahby, 2000). Because Nt test depends on living host system, it is costly, time consuming and the interpretation of neutralizing titers is influenced by subjective visual scoring of cytophatic effects (CPE). More rapid identification has been attempted using negative staining electron-microscopy, immunofluorescence or immunoelectrophoresis. These techniques are not always applicable to screening of large number of samples.

EIA offers several advantages, including speed, easy to perform and objective results (Middeldorp et al., 1987; Gleaves et al., 1990; Deshpande, 1996). It is the most widely used of all immunological assay for antibodies and antigens, since large number of test can be performed in

${ }^{*}$ Author for correspondence 
relatively short time with maximum of sensitive and minimum technical expertise and equipment (van Weemen, 1985; Pillot, 1996).

This work describes the development of an EIA for the detection of poliovirus antigen. The assay is useful for monitoring virus circulation in the environment, such as, in sewage treatment plant, water resources, poliomyelitis vaccine campaign and in the evaluation of anti-poliovirus compounds.

\section{MATERIALS AND METHODS}

\section{Virus and cell culture}

Poliovirus type 1 (ATCC, 192-VR) was propagated in LLC-MK 2 (monkey kidney) cell cultures cultivated in Dulbecco's Modified Eagle's Medium (DMEM) (Sigma Chem. Co., USA.) supplemented with $7 \%$ fetal bovine serum (Gibco BRL, USA), $100 \mu \mathrm{g} / \mathrm{ml}$ streptomycin, $100 \mathrm{UI} / \mathrm{ml}$ penicillin (Sigma Chem. Co., USA) and $2.5 \mu \mathrm{g} / \mathrm{ml}$ fungizon (Bristol-Myers Squibb, Brazil).

\section{Antigen}

The supernatant fluid of virus-infected cell cultures was harvested when cultures showed maximal CPE, 24-48 hours post-infection. Virus titer was determined as $0.5 \times 10^{6} \mathrm{TCID}_{50} / \mathrm{ml}$. Briefly, the supernatant fluid of infected cell cultures was clarified by centrifugation at $10,000 \mathrm{x}$ $\mathrm{g}$ for $30 \mathrm{~min}$. Partial concentration of virus was carried out by the addition of polyethylene glycol $6000(8 \%, \mathrm{w} / \mathrm{v})$, at $4^{\circ} \mathrm{C}$ overnight under agitation, and followed by centrifugation at $10,000 \mathrm{x}$ g for $30 \mathrm{~min}$ at $4^{\circ} \mathrm{C}$. The resulting precipitate was resuspended in phosphate-buffered saline (PBS), $\mathrm{pH} \mathrm{7.4}$, and 1.0-2.0 ml layered on a cushion of $20 \%$ sucrose in PBS, and ultracentrifuged at $100,000 \mathrm{x} g$ for $3 \mathrm{~h}$. The pellet was resuspended, protein content was determined, and the material was stored at $-20^{\circ} \mathrm{C}$.

\section{Immunization}

Rabbits and guinea pigs were inoculated five times with $0.2 \mathrm{ml}$ purified viral antigen emulsified with Freund's complete adjuvant, at a week interval. The animals were bled by cardiac puncture seven days after the final booster. Following inactivation at $56^{\circ} \mathrm{C} / 30 \mathrm{~min}$, sera were adsorbed with $10^{5}$ cells/ml (LLC-MK ${ }_{2}$ ), and immunoglobulin was precipitated with ammonium sulfate. Protein contents were determined accordingly.

\section{Antibody titers}

Double immunodiffusion in agar gel was used for screening hyperimmune sera. Neutralization test was carried out as follows. Test sera were prepared in two fold dilution (from 1:2 on) in cell culture maintenance medium. Thereafter, $100 \mu 1$ of each dilution were pooled with an equal volume of 100 $\mathrm{TCID}_{50} / \mathrm{ml}$ of poliovirus and incubated at $37^{\circ} \mathrm{C}$ for 1h. This was followed by inoculation onto cell monolayers grown in 96-well tissue culture plates and incubation at $37^{\circ} \mathrm{C}$ for 5 days in $5 \% \mathrm{CO}_{2}$ atmosphere. The antibody end point titer was determined as the highest dilution that inhibited CPE.

\section{Checkerboard titration}

Optimal concentrations of guinea pig and rabbit immunoglobulins were determined by checkerboard titration on microtiter plates. Briefly, polystyrene microtiter plates (Hemobag, Brazil) were coated with $100 \mu \mathrm{l}$ per well of guinea pig antibodies containing $1.5 \mu \mathrm{g} / \mathrm{ml}$ (half plate) and $15.0 \mu \mathrm{g} / \mathrm{ml}$ (half plate) protein in $0.1 \mathrm{M}$ carbonatebicarbonate buffer, $\mathrm{pH} 9.6$, overnight, at $4^{\circ} \mathrm{C}$, in a humidified chamber. Plates were washed twice with PBS, pH 7.2, containing $0.05 \%$ Tween 20 (PBS-T). The coated plates were blocked with 200 $\mu \mathrm{l} /$ well of blocking solution (PBS, $\mathrm{pH}$ 7.2, containing $2 \%$ skimmed milk powder and $0.05 \%$ Tween 20) for $90 \mathrm{~min}$ at $37^{\circ} \mathrm{C}$. Plates were washed with PBS-T throughout. Antigen at the concentration of $0.03,3.0$ and $30 \mu \mathrm{g} / \mathrm{ml}$, in replica, was used as positive control at a volume of 100 $\mu 1 /$ well. Blank was performed with PBS instead. Incubation was followed at $37^{\circ} \mathrm{C}$ for $60 \mathrm{~min}$. Plates were washed with PBS-T. Aliquots of $100 \mu \mathrm{l}$ of rabbit antibody, diluted in a serial dilution from $127.0 \mu \mathrm{g} / \mathrm{ml}$ to $2.0 \mu \mathrm{g} / \mathrm{ml}$, in blocking solution were added and the plates were incubated at $37^{\circ} \mathrm{C}$ for $60 \mathrm{~min}$. Incubation was followed by washing and the addition of $100 \mu \mathrm{l}$ of goat anti-rabbit IgG peroxidase-conjugate (Sigma Chem. Co., USA) at 1:40,000 in blocking solution for $60 \mathrm{~min}$ at $37^{\circ} \mathrm{C}$. Plates were washed and followed by the addition of $100 \mu \mathrm{l}$ of substrate $\left(0.03 \% \mathrm{H}_{2} \mathrm{O}_{2}\right.$ and $400 \mu \mathrm{g} / \mathrm{ml}$ $o$-phenylenediamine dihydrochloride) (Sigma Chem. Co., USA) diluted in $0.05 \mathrm{M}$ citratephosphate buffer, $\mathrm{pH} 5.0$. After $15 \mathrm{~min}$ at $25^{\circ} \mathrm{C}$ in light tight box, the reaction was stopped by the addition of $50 \mu 12 \mathrm{~N} \mathrm{H}_{2} \mathrm{SO}_{4}$ and the optic density (OD) was read at $490 \mathrm{~nm}$. 


\section{Antigen standard curve for dose response}

The standard curve was generated from decreasing antigen concentration ( 300.0 to $2.3 \mu \mathrm{g} / \mathrm{ml}$ ) in eight replicas by previous protocol with immunoglobulin concentrations optimized by checkerboard titration $(15.0 \mu \mathrm{g} / \mathrm{ml}$ for capture antibody and $7.94 \mu \mathrm{g} / \mathrm{ml}$ for detector antibody).

\section{Statistical analysis}

The standard curve was used to estimate the doseresponse relationship and the variation of the analyte (antigen) concentration estimated by the coefficient of variation $(n=8)$. The dose-response was determined by linear regression. The analysis was based on the number of data points and the correlation coefficient $\left(\mathrm{R}^{2}\right)$. Normally, at least four data points were included and a $R^{2}$ equal or larger than $95 \%$.

\section{Clinical specimens}

Five fecal specimens from children between one to two years of age were collected in June and July 2003 after the poliomyelitis vaccination campaign, maintained in $-20^{\circ} \mathrm{C}$, were supplied by the Laboratório LAPAC (Ponta Grossa- PR). Four replicates of each sample diluted at 1:10 were tested by the previous optimized condition.

\section{Cut-off}

The cut-off value was established according to Porstmann and Kiessig (1992).

\section{RESULTS}

Optimal concentrations of capture and detector immunoglobulins were determined by checkerboard titration against the antigen used for immunization. The initial analysis indicated high background due to an excessive non-specific binding (NSB) hampering distinction of a positive signal derived from the analyte against the blank values. NSB was minimized by increasing blocking agent concentration from 1 to $2 \%$. The concentration of guinea pig antibody (capture) of $15.0 \mu \mathrm{g} / \mathrm{ml}$ demonstrated a better result than 1.5 $\mu \mathrm{g} / \mathrm{ml}$. The slope of the curve indicated that suitable results would be achieved by the use of $15.0 \mu \mathrm{g} / \mathrm{ml}$ of capture antibody and $7.94 \mu \mathrm{g} / \mathrm{ml}$ of rabbit antibody (detector) (Fig.1).

By the standard curve, the precision and the quantitative aspect of the assay could be evaluated (Fig.2).

The precision, also referred to as reproducibility, a measure of variation between repeated determination of the same sample, was determined by the CV. Different concentrations of antigen were used to evaluate the performance of the method in the same day in eight replicas and the CV varied from 2.1 to $7.8 \%$ (Fig.3). When evaluating the dose-response by standard curve for decreasing concentration of reference antigen, a sigmoid curve was obtained. Simple linear regression was used to determine if the assay showed a statistically significant dose-response relationship.

Antigen concentrations chosen empirically was analyzed to reach the best correlation $\left(\mathrm{R}^{2}\right)$ between $\mathrm{OD}$ and antigen concentration.

The linear interval occurred between 2.3 and 37.5 $\mu \mathrm{g} / \mathrm{ml}$ and resulted in a dose-response relationship represented by $\mathrm{OD}=0.0124 \times[\mathrm{Ag}]+0.4396,(\mathrm{Ag}$ is the antigen concentration), with the coefficient of correlation, $\mathrm{R}^{2}$, equal to $96.4 \%$. In optimized condition, assay detected cell antigen only at levels higher than $730 \mu \mathrm{g} / \mathrm{ml}$ indicating a low level of cross-reaction with cell antigen. The assay detected a minimum of $2.3 \mu \mathrm{g} / \mathrm{ml}$ polio antigen. The clinical samples resulted in OD of 0.146 , $0.164,0.201,0.227$, and 0.356 , while the cut-off value resulted in an OD of 0.141 .

\section{DISCUSSION AND CONCLUSION}

The purpose of this work was to establish a solidphase enzyme immunoassay for the detection of poliovirus antigens. As commented previously, instead of focusing in disease diagnosis, the current assay was developed for monitoring poliovirus circulation in the environment. Moreover, the assay could be also important as a tool for assessing poliovirus replication with the purpose of antiviral studies. 


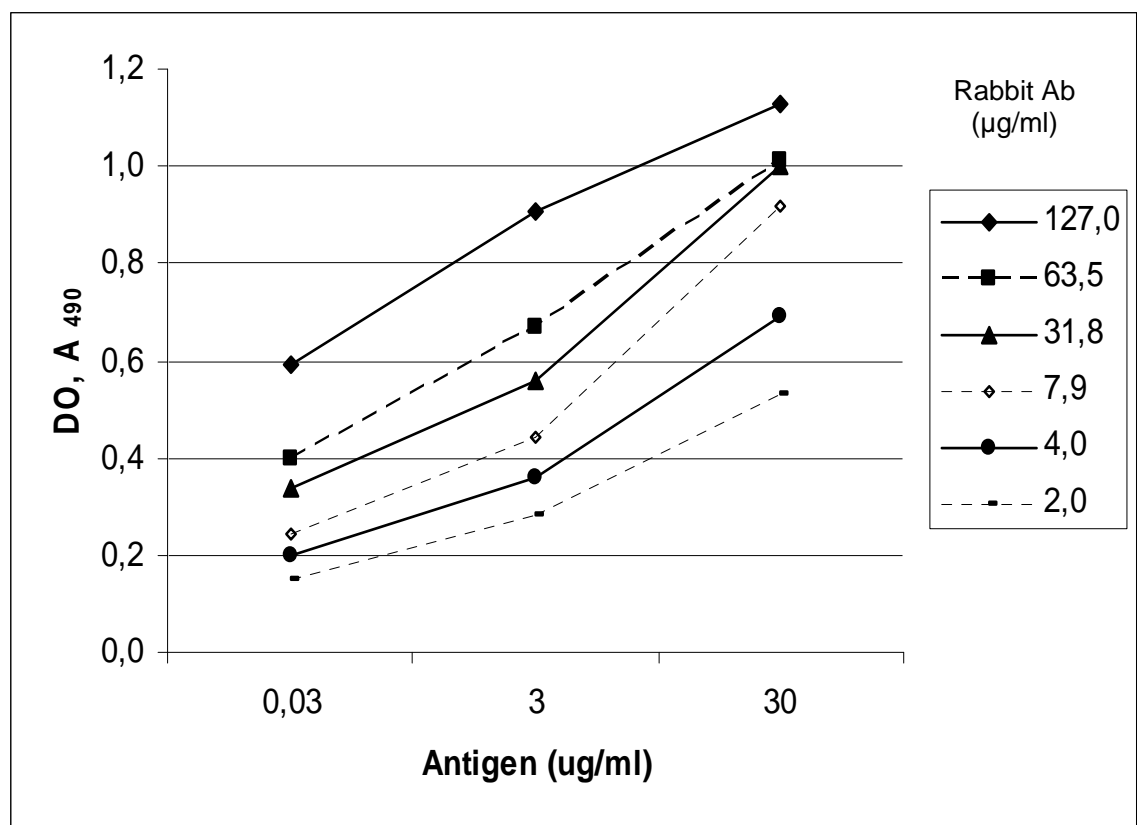

Figure 1 - Checkerboard titration for rabbit antibodies (Ab) tested with blank, 3.0, and 30.0 $\mu \mathrm{g} / \mathrm{ml}$ of poliovirus antigen, on plates coated with $15.0 \mu \mathrm{g} / \mathrm{ml}$ of guinea pig detector antibodies.

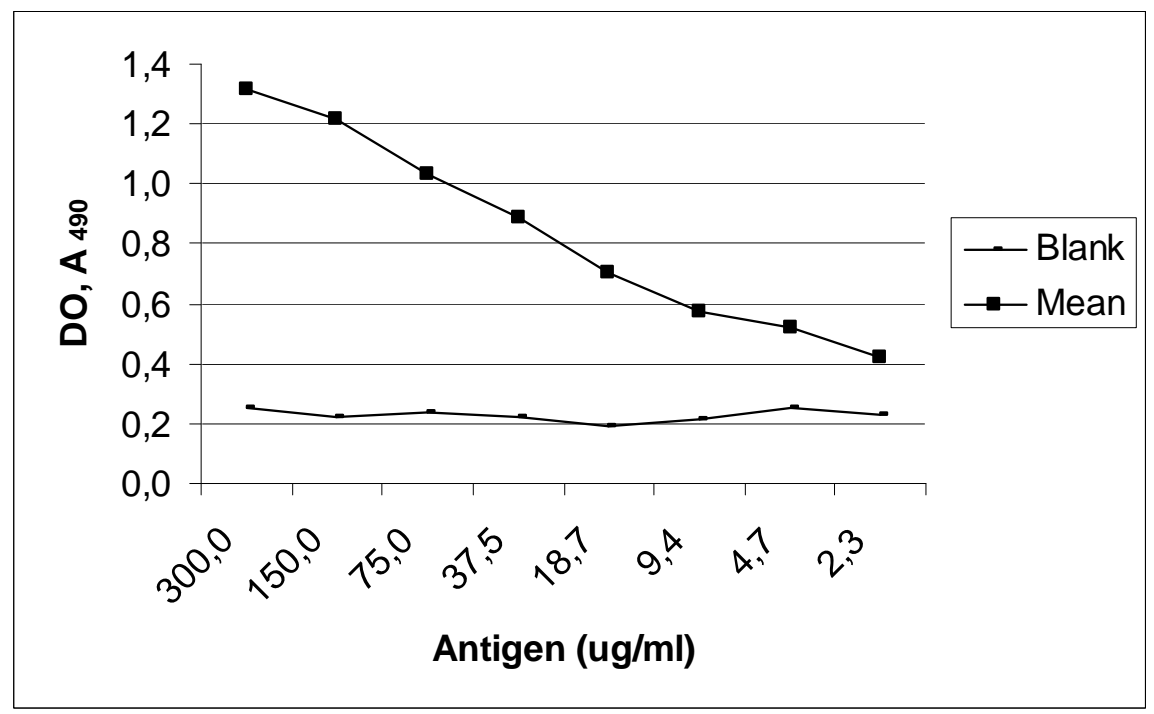

Figure 2 - Standard curve of poliovirus antigen. Arithmetic mean of eight replicates. 


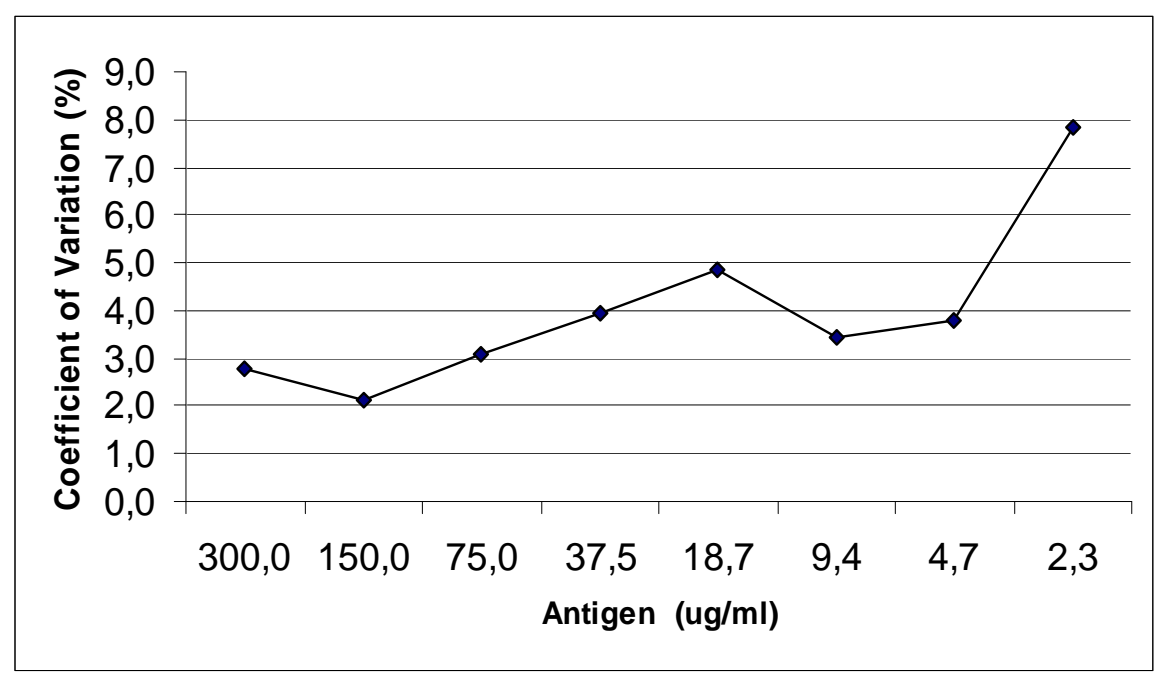

Figure 3 - Coefficient of variation for different concentrations of poliovirus antigen $(n=8)$.

Serological methods for poliovirus antigens detection evolved from complement fixation test to gel diffusion based on the detection of soluble and particulate (virus particles) antigens with low sensitivity.

The adaptation of EIA using poli- or monoclonal antibodies increased sensitivity and specificity for testing, particularly, the potency of inactivated poliovirus vaccine (Singer et al., 1989). Ukkonen et al. (1986) developed an EIA for the detection of poliovirus antigens in feces with a sensitivity between 2 to $5 \mathrm{ng} / \mathrm{ml}$. However, due to small amount of poliovirus in feces the authors concluded that the assay was not suitable. In poliovirus natural infection it was determined that the titer of the virus shed in stool could vary from $10^{2}-10^{7}$ TCID $_{50} / \mathrm{ml}$ (Krugman et al., 1961). Most of EIA detect antigen at level of $1 \mathrm{ng} / \mathrm{ml}$ (Deshpande, 1996). By deduction, this concentration was equivalent to $10^{8}$ virus particles/ml (Ukkonen et al., 1986). Studies demonstrated that human feces rarely contain poliovirus at high titer (Payment et al., 1982; Ukkonen et al., 1986). This assay detected a minimum of $2.3 \mu \mathrm{g} / \mathrm{ml}$ polio antigen, considering that particulate and soluble antigens were used to obtain antisera. Both capture and detector antisera demonstrated neutralizing antibodies titers of approximately 1:5,120 (data not shown). The performance of present assay demonstrated results reasonable by the analysis of the $\mathrm{CV}$, varying from 2.1 to $7.8 \%$. The estimated variation should be below $15 \%$ to be recommendable, whereas, $30 \%$ would be the maximum acceptable value for repeatability of a diagnostic test (Porstmann and Kiessig, 1992; Deshpande, 1996; Gubbels et al., 2000). Using a better purified antigen, either particulate only or particulate and soluble antigens probably would increase the sensitivity of this test. The low sensitivity of the test associated with low titer of poliovirus in vaccinees clinical specimens could be the cause of OD values close to that of the cut-off for two specimens. Polioviruses grown in suitable cell cultures, even at low passage, render high titers, such as $10^{14} \mathrm{TCID}_{50} / \mathrm{ml}$ in HEp-2 cell cultures (human larynx carcinoma cells) (personal communication). Based on this property, the use of this test for monitoring poliovirus adapted in cell culture could be useful, such as, in antiviral studies, and water source contamination where virus concentration was required. In conclusion, the proposed test could have a potential use for laboratorial studies where cell culture adapted poliovirus was used or virus particles were accordingly concentrated.

\section{ACKNOWLEDGEMENTS}

This work is part of NH M.Sc. manuscript. It was partially supported by CAPES-ds, CNPq, Fundação Araucária and Propprg/UEL. The authors thank to Embrapa Soja (Dr. A.M.R.Almeida) for the ultracentrifugation facilities. 


\section{RESUMO}

O trabalho apresenta o desenvolvimento de um ensaio imunoenzimático indireto para a detecção de antígeno de poliovírus. $O$ antígeno viral foi obtido em cultura de células LLC-MK $\mathrm{MK}_{2}$ e usado para imunização de coelho e cobaia. Os soros hiperimunes foram avaliados por imunodifusão dupla e teste de neutralização. Após padronização, o soro de captura, produzido em cobaia, foi usado na concentração protéica de $15.0 \mu \mathrm{g} / \mathrm{ml}$ para sensibilizar microplacas de poliestireno e o soro de coelho (detector) foi usado na concentração de $7.94 \mu \mathrm{g} / \mathrm{ml}$. A curva padrão resultante da utilização de oito diferentes concentrações do antígeno padrão definiu um coeficiente de variação de $2.1 \%$ a $7.8 \%$. A relação dose-resposta foi determinada por regressão linear simples com o estabelecimento do coeficiente de correlação $\left(R^{2}\right)$ igual a $96.4 \%$. O ensaio possibilitou a detecção mínima de $2.3 \mu \mathrm{g} / \mathrm{ml}$ de antígeno de poliovírus.

\section{REFERENCES}

Deshpande, S. S. (1996), Immunodiagnostics: a historical perspective. In: Enzyme Immunoassays: From Concept To Product Development. Chapman and Hall, New York, pp. 8-12.

Engleberg, N. C. (1999), Diagnostic principles. In: Microbial Disease, eds. M. Schaechter; N.C. Engleberg; B.I. Eisenstein and G. Medoff, $3^{\text {rd }}$ edition, Lippincott Williams and Wilkins Co., Philadelphia, pp. 503-512.

Gleaves, C. A.; Rice, D. H. and Lee, C. F. (1990), Evaluation of an enzyme immunoassay for the detection of herpes simplex virus (HSV) antigen from clinical specimens in viral transport media. J. Virol. Methods, 28, 133-140.

Gubbels, M. J.; Oliveira, C. and Jongejan, F. (2000), Development of an indirect Tams 1 enzyme-linked immunosorbent assay for diagnosis of Theileria annulata infection in cattle. Clin. Diagn. Lab. Immunol., 7, 404-411.

Krugman, S.; Warren, J.; Eiger, M.; Berman, P. H.; Michaeles, R. M. and Sabin, A. B. (1961), Immunization with live attenuated poliovirus vaccine. Am. J. Dis. Child., 101, 23-29

Lennette, D. A. (1995), General principles for laboratory diagnosis of viral, rickettsial, and chlamydial infections. In: Diagnostic Procedures for Viral, Rickettsial and Chlamydial Infections, eds. E. H. Lennette; D. A. Lennette and E. T. Lennette, $7^{\text {th }}$ edition, American Public Health Association, Washington, pp. 3-11.

Middeldorp, J. M.; Hooymans, A. M.; Kocken, A. J. H. F.; Loon, A. M.; Emsbroek, J. A. and Coutinho, R. A. (1987), A sensitive enzyme-linked immunosorbent assay for the detection of herpes simplex virus antigens. J. Virol. Methods, 17, 159-174.

Pallansch, M. A. and Roos, R. P. (2001), Enteroviruses: Polioviruses, Coxsackieviruses, Echoviruses and newer Enteroviruses. In: Virology, eds. B. N. Fields; D. M. Knipe; P. M. Howley et al., 4th edition, Lippincott Williams and Wilkins Co., Philadelphia, pp. 723-775.

Payment, P.; Tremblay, C. and Trudel, M. (1982), Rapid identification and serotyping of poliovirus isolates by an immunoassay. J. Virol. Methods, 5, 301-308.

Pillot, J. (1996), The year of Pasteur: from the concept of antibody and antigen by Bordet (1895) to the ELISA. What future for immunological diagnosis? Clin. Diagn. Virol., 5, 191-196.

Porstmann, T. and Kiessig, S. T. (1992), Enzyme immunoassay techniques - an overview. J. Immunol. Methods, 150, 5-21.

Singer, C.; Knauert, F.; Bushar, G.; Klutch, M.; Lundquist, R. and Quinnan Jr., G. V. (1989), Quantitation ofpoliovirus antigens in inactivated viral vaccines by enzyme-linked immunosorbent assay using animal sera and monoclonal antibodies. J. Biol. Stand., 17, 137-150.

Ukkonen, P.; Huovilainnen, A. and Hovi, T. (1986), Detection of poliovirus antigen by enzyme immunoassay. J. Clin. Microbiol., 24, 6, 954-958.

van Weemen, B. K. (1985), ELISA: Highlights of the present state of the art. J. Virol. Methods, 10, 371-378.

Wahby, A. F. (2000), Combined cell culture enzymelinked immunosorbent assay for quantification of poliovirus neutralization-relevant antibodies. Clin. Diagn. Lab. Immunol., 7, 915-919.
Received: June 10, 2005; Revised: November 23, 2005; Accepted: October 16, 2006. 